\title{
The costs of compliance? Views of Sri Lankan apparel manufacturers in times of global economic crisis
}

\author{
Kanchana N. Ruwanpura* and Neil Wrigley \\ School of Geography, University of Southampton, Southampton SO17 1BJ, UK \\ *Corresponding author: Kanchana N. Ruwanpura, School of Geography, University of Southampton, \\ Southampton SO17 1BJ, UK. email<k.n.ruwanpura@soton.ac.uk>
}

\begin{abstract}
Complementing the rise of ethical trading initiatives there has been a parallel growth in the number of academic studies tracking their origins and evolution, and assessing the implementation and success of social auditing practices. Despite this, the consequences and responses to the implementation of codes of conduct relating to labour standards at sites of production remains an understudied topic. This article focuses on those issues in the context of the global apparel industry using evidence from interviews with managers in the Sri Lankan garment manufacturing sector. In particular, it focuses on the contradictions and tensions inherent in compliance, and the anxieties management face during a period of global economic crisis, in a country which is generally considered to be in the vanguard of promoting and protecting ethical labour standards.
\end{abstract}

Keywords: Corporate codes, Sri Lanka, economic crisis

JEL classifications: J80, L81

Date submitted: 15 April 2010 Date accepted: 8 November 2010

\section{Introduction}

Corporate codes of conduct in the Global South have proliferated as a result of trade union activity and NGO campaigns against poor labour conditions in global production systems (Hale and Wills, 2007; McIntyre, 2008). Complementing this rise in ethical trade initiatives is a parallel growth in the number of academic studies tracking their origins and evolution, and assessing the implementation and subsequent success of social auditing practices (Blowfield, 1999, 2007; Barrientos and Smith, 2007; Hughes et al., 2007, 2008). All underscore the proliferation and diversity of code initiatives - sometimes not without confusion to suppliers - which have emerged from voluntary individual company codes through to multi-stakeholder initiatives, with some variations attributable to the location of the retailer's host country (Hughes et al., 2007). Despite this, the consequences of and responses to the implementation of codes of conduct relating to labour standards at sites of production remains an understudied topic. In response, this article focuses on these issues in the context of the apparel industry, using primary evidence from interviews with managers in the Sri Lankan apparel industry to reveal business-level responses to ethical trade initiatives and in particular to explore the challenges of compliance during a global economic crisis. 
The material reported on this article is drawn from a wider 3-year Economic and Social Science Research Council (ESRC) funded project which seeks to explore the ways in which ethical corporate codes have bearing upon evolving labour practices at apparel production sites. ${ }^{1}$ The initial phase of the fieldwork conducted during December and January 2008-2009 involved 25 interviews in Sri Lanka with seniorand middle-level management from apparel producers in Sri Lanka to buying offices of UK and US high street brands. Table 1 (see Appendix A) provides a break down of the key characteristics of the interviewees. As the table indicates, management from a range of firms - large and small, urban and rural, foreign- and locally owned - were contacted for this study. As such we have attempted to capture the views of a diverse set of firms within the apparel sector in Sri Lanka-views which tended to highlight the impact of the global economic crisis and the producer's unease in relation to ethical codes.

The interviews were carried in a range of locations, from production factories and management offices to meetings at the homes of senior management. Each interview lasted no less than 40 minutes with some interviews lasting as much as 1.5 hours. The interviews were characterized by a high degree of frankness due to the familiarity and language affinity of the principal investigator (PI) and the interviewees. Our purpose was not to establish the intentions of management when they deploy codes at sites of production, rather their views on the nature of competitive compliance, and the degree to which it is now under stress because of the economic downturn. As Schoenberger (1991, 183) noted corporate interviews can be particularly invaluable during 'periods of great economic and social change that pose new challenges'. Yet, as she also points out there are limits and potential to conducting management interviews, where their views are 'filtered through processes by which (they) make sense of their own experiences' (Bourdieu, 1977, cited in Schoenberger, 1991, 183). We are aware that there may be a disjuncture between management perspectives and labour practices on the ground. Not withstanding this limitation, however, there is a case for recording managers' perceptions on how national regulation, local institutions and social development facets are also an important sieve for how code governance regimes are implemented - an important area which academic commentary on ethical sourcing has tended to ignore or bypass. Because of confidentiality agreements with the interviewees and ethical considerations, the identity of managers are not revealed in the text.

The article begins with discussion of the global apparel industry - an industry that has been at the forefront of the implementation of ethical trading initiatives and social auditing practices. Globally, the academic literature has also focused on the industry's up-scaling strategies. The tenuous relationship between enforcement of corporate codes and industry up-scaling remains insufficiently explored. In Sri Lanka, however, the apparel industry has been at the forefront of the implementation of ethical trading initiatives and social auditing practices partly to drive an up-scaling strategy. ${ }^{2}$ As a

1 The 3-year project is designed to include interviews with management as a way of gaining trust in the first instance. This is was so as to embed a Research Assistant for a 2-year period [and the PI (for a 7-month period)] at apparel production sites with a view to interviewing 80 workers over a period of time and track the ways in which corporate codes are upheld or broken through a system of journal entry keeping by 25 workers.

2 For instance, the 'Garments without Guilt' initiative by the Joint Apparel Association Forum (JAAF) is an industry-based effort which seeks to position and locate Sri Lanka as the 'World's \#1 Ethical Sourcing Destination' and make the ' "Made in Sri Lanka' label synonymous with quality, reliability, social and environmental accountability" (http://www.garmentswithoutguilt.com/). In this respect, the motivation 
result, in order to highlight the national economic, social and institutional contexts in which these initiatives have evolved, an outline of the economic and political dimensions of the evolution of labour standards in Sri Lankan garment production is then provided. Discussion then moves to ethical trade initiatives, and the implementation of codes of conduct. In particular, findings from our Sri Lankan management interviews are used to explore supplier frustrations with the contradictions inherent in attempting to remain complaint with ethical trading agendas - especially as those costs of compliance are perceived to have become more onerous during a severe global economic downturn. Given that our study was undertaken during the depths of the global recession our findings are opportune, and is likely add value to emerging academic debate on the likely robustness of ethical trading initiatives during times of economic crisis.

\section{Global garments and corporate codes: theorizing tenuous links}

In recent years, the global garment industry has been widely examined in the academic literature with a number of studies attempting to shed light upon the industry's unique characteristics. The development of full-package suppliers, industrial upgrading, the complex interplay between local and regulatory governance regimes and the dynamics and driving mechanisms of the industry have been the foci of interest thus far (Gereffi et al., 2005; Bair, 2006; Neidik \& Gereffi, 2006, Pickles et al., 2006; Tewari, 2006). The literature also notes how global supply networks which underpin the garment industry are marked by an unevenness of power relations (Mayne, 1999; Hughes, 2001, 2005; Knutsen, 2004; Palpaceur et al., 2005; Thomsen, 2007; Coe et al., 2008; Nadvi, 2008; Tokatli et al., 2008) - the asymmetries of which, in the view of Coe et al. (2008), determine the agendas that can be realized in the industry. In turn, this conceptualization of uneven power dynamics has offered a framework for studies of global trade networks. The compromised position of developing economies situated within global commodity chains and the limited prospects for development via process standards has already been illustrated (Smith et al., 2002; Palpaceur et al., 2005; Thomsen, 2007; Nadvi, 2008). They openly question how far global-value chains (GVCs) can take developing countries in the industrialization process and cite ways in which inequalities and limitations, manifest in the form of entry barriers and trade restrictions, are imposed upon the suppliers from the Global South embedded into global sourcing networks. Such studies confirm how the imbalance and uneven nature of governance, which is at the heart of much of the literature on economic geographies of globalization, continues to plague the workings of value chains (Webber and Weller 2001; Hughes, 2005; Coe et al., 2008; Nadvi, 2008, Tokatli et al., 2008).

Set within this context of uneven power dynamics, we observe that direct and indirect pressure from NGOs and media campaigns which targeted clothing retailers and 'brand marketers' during the 1990s led to larger retailers in the apparel sector being among the first to accept an agenda for corporate social responsibility that included labour standards (Hale and Shaw, 2001, 511; Hale and Wills, 2007; McIntyre, 2008).

to make Sri Lankan apparel ethical is also perceived as good business strategy that coincides with its quest to upscale and move into eco-friendly apparel production as well. Tracing the up-scaling strategies of the industry is, however, for another research article. 
Furthermore, the pressure on brand retailers to adopt social responsibility towards labour was compounded with the vertical disintegration within the apparel sector, which had led factories and suppliers outsourcing contracts to smaller firms with concomitant proliferation of casual and temporary labour force (Kabeer, 2004; Hale and Wills, 2007). Subsequently, the industry has been heavily scrutinized by academic investigation to determine levels of compliance with such ethical trading initiatives. Investigations have pinpointed several facets of the apparel sector that shape the implementation and impact of ethical initiatives. For example, Hale (2000), Hale and Shaw (2001) and Hale and Wills (2007) emphasize the pervasive use of subcontracted firms by major retailers suggesting that it is both an endemic feature and obstacle within the industry, resulting in disjointed and often untraceable supply networks (see also Knutsen, 2004; Neidik \& Gereffi, 2006; McIntyre, 2008). Claims have also been advanced that auditing practices mirror these global power imbalances, with neo-colonial and Western models of development appearing to largely determine auditing practices and content of corporate codes (Freidberg, 2003; Hughes, 2005). This literature, however, by and large has tended to neglect the role of national regulation in the process - favouring instead to honing in on the governance regimes of transnational retailers.

Whilst a great deal can be learnt from investigating the ethical trade agendas of retailers and the shift in responsibility to the corporate realm, the power-laden practices through which codes are developed must be understood from both sides of the supply network. Hughes (2005) and Hughes et al. (2007) open up significant pathways into the study of corporate agency in the implementation of codes by investigating the contrasting strategies deployed by retailers. Hughes et al. (2007) engages with how such corporate ethical agendas are differently influenced by, and embedded within nationalinstitutional contexts, ${ }^{3}$ and thereby point to the differentiated nature of corporate codes which emanate from the USA-UK context. Much of the work of Hughes (2005) and Nadvi (2008), however, advances corporate agency as the organizational principle driving the configuration of ethical supply chains. Yet, as Nadvi (2008) points out, these efforts and such a narrow approach is not without pitfalls and challenges. By spreading production over a number of sources across a region retailers have been able to gear their supply chains towards greater flexibility, ensuring higher-profit margins but this has been at the cost of dispensing risk towards the peripheries of the supply networks (Hughes, 2001; Webber and Weller, 2001; Tokatli et al., 2008).

Nadvi (2008), in particular, emphasizes that a 'failure to take ownership of the agenda on standards and to socially embed the values explicit in external standards in the local milieu... (can have) weak governance outcomes' (2008, 340). His intervention serves as a reminder of the need to take into consideration the local and institutional context within which corporate codes are put into practice, and Nadvi's $(2008,11)$ case study of Nike's experiences in Pakistan emphasizes Sunley's (2008) stress on the need to pay attention to how 'economic relations and networks vary among different national, regional and local expressions of these contexts' (see also Smith et al., 2002; Weller, 2007). In contrast, we note a relative under-emphasis of institutional context at the

3 Their contribution, however, exclusively focuses on the role of the retailers' country of origin in the Global North in shaping approaches to improving labour standards and highlights the role of nationaland consumer-driven corporate ethical strategies (Hughes et al., 2007, 495). They, however, do not delve into politics of corporate governance as they transmit across uneven development spaces and interact with local institutional contexts in the Global South (De Neve, 2009; see also Nadvi, 2008). 
heart of the governance literature on GVCs, which notes that 'variables internal... influence the shape of governance of global values chains ... regardless of the institutional context within which they are situated' (Gereffi et al., 2005, 99), and we suggest that the lack of attention to the institutional context in the Global South as corporate codes are implemented is a partial reason for the limited academic contribution on understanding the ways in which labour practices have evolved in response to governance regimes. In contrast, our contribution in this article focuses on understanding the ways in which the local institutional context has a bearing on labour practice responses to ethical codes - albeit from the perspective of management.

A historically forceful labour movement and union politics in Sri Lanka have had some bearing on holding management responsible for upholding labour standards, which have converged with corporate and ethical code regimes to some degree. As a result, we observe that institutional context and the central import of national labour regulation and histories must not be neglected from any analysis of code compliance, and the ways they contribute to upholding code governance regimes. Despite such advantages, operating in an uneven global terrain is not without its pressures and pervasive imbalances of power, which is an endemic feature of the apparel industry at all geographical levels. Many of our Sri Lankan management interviews confirmed the risky, compromised and weakened position that this placed suppliers into-especially in the context of the rise of what has come to be known as 'fast fashion' (Tokatli, 2007a, 2008; Tokatli et al., 2008) with its associated exactingly tight production deadlines and frequent design changes. Indeed, academics have perceived these uncompromising dynamics to have produced a tension-reflected in debate between civil society organizations and retailers-concerning whether fast fashion sourcing strategies of retailers are incompatible with implementation of codes of conduct at sites of production (Hale, 2000; Hughes, 2001; Pearson and Seyfang, 2001; Knutsen, 2004; Pickles et al., 2006; Barrientos and Smith, 2007).

During global economic crisis, we find that these incompatibilities have become more pronounced and that there has been a growing unwillingness to reward suppliers for maintaining compliant standards. This is in contrast with concerted efforts by actors involved in holding retailers accountable, who now directly target retailers' sourcing managers to make a business case for responsible sourcing and to mitigate impacts on workers from the global recession (Impactt and Traidcraft, 2009). While a fixation with price is not itself a novelty, the willingness to overlook compliance for price considerations under economic pressure is recent and keenly felt. More generally, the ways in which 'economic pressures and market forms shape behaviour and opportunities for different forms of social interaction' (Sunley, 2008, 10) has been starkly brought to the fore within buyer-supplier relationships during recessionary times, with very real consequence for labour practices and conditions. Indeed, the crux of the issue, as Hale $(2000,350)$ pointed out, is whether: 'in labour-intensive industries, ethical policies, such as the implementation of conduct codes, [can] survive in the context of downward pressures on labour costs and conditions?'

\section{Cut above the rest? Contextualizing Sri Lankan apparels}

The importance of the global apparel trade to the Sri Lankan economy cannot be understated. Apparel exports have been the largest source of net foreign exchange 
earnings to Sri Lanka for more than a decade (Saravanathan and Sanjeewani, 2008) and garment exports now contribute significantly to the economy, accounting for $50 \%$ of total exports (Yatawara, 2007). Furthermore, he notes that the sector employs 37\% of workers involved in manufacturing, equal to $5 \%$ of the country's entire labour force.

In contrast to wider shifts in global apparel supply networks where 'fast fashion' production cycles are becoming the norm in countries such as Turkey, Morocco, Central and Eastern Europe with proximity to major consumer markets in Western Europe (Pickles et al., 2006; Tokatli, 2008; Tokatli et al., 2008), Sri Lanka's apparel production cycles have remained more seasonal (Spring/Summer and Autumn/Winter) in nature, supplemented by some core products - whites, blacks and nudes in intimates for instance-continuously produced. ${ }^{4}$ Nevertheless, Sri Lanka has increasingly attempted to move into ethically sourced higher value-added production-moving away from basics (including knitwear and T-shirts) into intricate embroidery, stitched embellishments and eco-friendly high-quality garments. In pursuing this up-grading strategy, the high-end Sri Lankan apparel manufacturers are establishing the country as the 'lingerie capital' supplying amongst others to Victoria's Secret, Marks and Spencer (the lingerie lines of Per Una and Autograph for example) and La Senza (see also Karp, 1999; O'Leary, 2009). ${ }^{5}$

The route towards industrial upgrading which Sri Lanka has followed and the extent to which it is dissimilar to that of its Asian competitors is both vital and understudied. In particular, that country-specific context which has resulted in Sri Lanka becoming a stronger advocate for the promotion and maintenance of the ethical production of apparel goods than many of its Asian rivals needs to be appreciated.

I think Sri Lanka is probably like...- it is a slightly different culture as well. Most of Sri Lanka is not dirt poor, like India or Bangladesh. I don't mean that in an insulting way; for Sri Lankans, social development was quite important - like universal franchise was here before Britain had it. So, in that sense... our people would have required, they would wanted to be treated differently and may be successive governments also pushed labour regulations to a high extent. And labour regulations are quite stiff here, which is both a positive and a negative (MM5)

If you visit any of our factories, you will see that we have superb conditions and they are really impressive standards. But we, the factory, have to bear the costs of all of this - and taking an ethical route means higher prices. All our factories are air-conditioned, offer meals and transport - and of course this puts cost up. Given the uncertainties and insecurities with the recession at the moment, we have wondered whether taking the ethical route is going to pay-off? (MM11)

To understand the context, we begin by summarizing how and why working conditions in Sri Lankan supply factories were already at a relatively high standard before the arrival of ethical trade initiatives and brand-name manufacturers. In particular, we note

4 However, our interviewees have mentioned that production lead times are constantly challenged and have dramatically reduced over time.

5 This is not to say that Sri Lanka's apparel sector exclusively produces only lingerie; it continues to export garments in non-knitted outerwear and knitted wear. Even as the apparel sector increasingly cultivates a marketing image of Sri Lanka as the 'lingerie capital', the reality was that in 2009 only $22.5 \%$ of export value came from lingerie. However, in terms of monetary value it was dwarfed only by shirt wear for women (Source: Sri Lanka Customs, 2010). 
how Knutsen (2004) points to the way the legal framework put in place during the British colonial period was responsible for laying down a regulatory infrastructure, ${ }^{6}$ a theme echoed in our management interviews:

I think they [corporate codes of conduct] were better implemented here, because Sri Lanka, Pakistan and India basically have the same labour laws. They were British rules. The difference is that Sri Lanka has already practiced them basically... (MM1).

Additionally, how the colonial period in a small country resulted in the long exposure to Western standards required by customers:

We [Sri Lanka] came to position the industry as an ethical sourcing destination. And that kind of came out of the fact that over the 20 to 25 year period that the industry has been in existence, they've [Sri Lankan garment manufacturers] consistently adhered to and improved on compliance standards. Most of what we find... was really kind of like inherent in the industrial mindset... Obviously being exposed to Western standards required by our customers definitely helped...(MM4).

The current position of wage labour and labour practices in Sri Lankan society needs then to be understood from a historical perspective. In particular, it is important to stress that the period from 1880 to 1933 - a time of significant adjustment for the Sri Lankan economy - was a critical period for the Sri Lankan labour force (Jayawardena, 1972). During that time, evolution of new forms of industrial organization triggered social conflicts and increasingly organized working-class agitation. Discontented by long hours, harsh working conditions, static wages and increasing costs of living as well as receiving little protection from state intervention, strikes and protests became common (Jayawardena, 1972). Influenced by the British Labour Party, the strength of Sri Lankan labour movements manifested themselves in the form of political parties and trade unions, which have subsequently asserted their autonomy with varying levels of success (Candland, 2002; Hale and Wills, 2007; Gunawardana and Biyanwila, 2008). This history of strong labour movements is evident in Sri Lanka economy today through the strength of both labour laws and the strict implementation of that regulation in comparison to neighbouring countries: ${ }^{7}$

Going back to the late 1980s - Premadasa's time and the Board of Investment (BOI) ... At that time, our factory that was socially compliant because Premadasa insisted on the BOI, he

6 As we note below, some care needs to be taken in placing credit in the labour laws put in place during the colonial rule to the benevolence of British rule. As Jayawardena (1972) has carefully shown, the progressive labour laws eventually put in place in Sri Lanka was hard won through bitter and sometimes violent struggle - where local labour activists came together with radical and progressive figures in the Labour Party of the day to introduce and push through protective labour legislation.

7 Gunawardana and Biyanwila's (2008) analysis of trade unions in Sri Lanka offers comprehensive, and yet linear, evolution and weakening space for union politics, particularly in the post-economic liberalization years. While they note instances in which unions have made gains or thwarted full-scale implementation of flexible labour market policies, they do not analyse the likely contingent and over determined nature of histro-political dynamics and the uneven application of this in the economic space. Quite in contrast, Gunawardana (2007) offers a more nuanced analysis of the key role union struggles have made to organizing and persevering the interests and rights of women workers - pointing to the multiple and contradictory nature of the struggle to improve working conditions and the possible moments of success too. 
insisted having locker rooms, number of toilers per worker, the requirement, the canteen area, and things like minimum wage, no child labour. I mean those things were very strict from the beginning in Sri Lanka because they were monitored by three bodies: one BOI, two from the labour department and also in the zones, it was monitored by the zone authorities... it had nothing to do with social compliance that comes with brands. That comes later on actually ... (SM1).

That is to say stringent rulings and issues of social compliance have been rigorously enforced and monitored by labour departments and other bodies, such as BOI, since the mid-1980s; long before brand-name retailers started to impose their own corporate social responsibility strategies.

Candland (2002, 66) for instance has argued that even as much of South Asia 'inherited identical labour legislation and (similar) national labour organizations ... their governments reworked them after independence in distinct ways'. In the case of Sri Lanka, in contrast to its neighbours, institutional practices led the Employer Federation of Ceylon to bargain with non-militant trade unions from its early days. Our management interviews suggest that these historical factors apparently continue to have resonance-highlighting the strong and respected position of labourers in Sri Lankan culture and political history. Indeed, in a context in which employer-employee relations in Sri Lankan factories are supposed to be characteristically strong and close-knit, with management attentive and sympathetic to the voices of their labour force (Wijesuriya, 2008). ${ }^{8}$ Our interviewees confirmed that employee welfare was valued by employers and that social interaction between management and workers is strong:

We have what we call line briefings, where we go up to the lines and interact with workers on a frequent basis to find out what pressing problems (including in their personal lives, because this affects their work) they may have and what we can do to improve the factory. This makes for a lot of interaction and familiarity with workers and this then also leads for them to feel free to raise these and other issues at the 'worker council' meetings. We try to create a convivial atmosphere between management and workers, because this ultimately helps boost worker morale and boost productivity. (MM6)

The result is that factory floor issues can be flagged up more easily by garment workers in Sri Lankan than in other Asian countries. ${ }^{9}$ In turn, that may help explain the

8 Lynch (2007) and Hewamanne (2007) using a cultural anthropology lens, however, are keen to point out that building kin relationships are a crucial means of disciplining and managing workers, especially women, to become a complaint labour force.

9 Some care needs to be taken in this particularly rosy picture that management were keen to paint. First, Ranaraja (2004) records how in many instances these 'welfare societies' or 'worker councils' are no substitute for the ILO conventions on freedom of association and management-instituted worker councils are actually a contravention of the core convention of freedom of association. Second, Gunawardana $(2008,83)$ notes how 'workers' council representation has limited influence' as most often the issues that get raised welfare issues rather than conditions of work. While, there is much veracity to these claims, the PIs on-going fieldwork at sites of production shows that there are also instances in which workers raise issues that have a bearing on some aspects of their conditions of work. However, these concerns are often brought-up when they pertain to individual worker representatives themselves and almost often are raised as individual problems rather than as affecting the collective. Along with this, there is also variation in the ways in which worker councils and welfare societies are a conduit for raising floor-level production issues - at some factories these are effective tools and is acknowledged as such by workers, while at other factories it is simply a society which ticks off a box pertaining to corporate codes. 
assertive stance of Sri Lankan labour departments in implementing ethical codes of conduct.

Our management interviews also confirmed previous findings by Knutsen (2004) and Yatawara (2007), which suggested that the relatively high levels of education amongst Sri Lankan garment workers has played a major role in developing and maintaining labour standards in Sri Lankan factories (see also Sluiter, 2009). Indeed a significant number of managers identified the high levels of education of the Sri Lankan labour force as the key factor underpinning and safeguarding prevailing levels of labour standards in garment factories. Unsurprisingly an educated labour force and high general literacy rates in the country are suggested to be major advantages for attracting manufacturing inward investment into Sri Lanka (Knutsen, 2004; Sluiter, 2009). They are also viewed as major drivers of the push for better working conditions, such as training programmes, and the willingness to flag-up code violations in the country's apparel factories. Arguably, these factors have allowed Sri Lanka to forge competitive advantage in terms of high labour standards and levels of compliance at sites of manufacturing and have been critical in helping the country steer clear of the 'sweatshop' culture and exploitative labour problems that seemed to have plagued many of its regional and global competitors in the apparel sector.

Additionally, the early arrival of Sri Lanka into the global market in comparison to that of other regional players in the industry, allowed it to gain and amass crucial experience on how to survive in the international capitalist economy and it has been well documented that such liberal economic policies served to stimulate the garment industry through investment and helped it shift towards higher value-added products (Knutsen, 2004; Yatawara, 2007). Indeed, Kelegama and Foley (1999 cited in Knutsen, 2004) note that $50 \%$ of Sri Lankan garment production is now aimed at the middle market, while an additional $10 \%$ is targeted towards the high-end market. As a result, and as noted in some of our management interviews, this shift moved the industry towards a more sophisticated level of production and encouraged both the adoption of more stringent approaches to the monitoring of labour standards and a greater pressure to maintain compliance to buyers' standards.

I think the industry has moved to a very sophisticated level of manufacturing... The emphasis on the people factor is very high. Because of that ... the structure and the foundation put in a number of years ago. Now today, you know, us being compliant is a given. I mean, we would hardly fail any compliance issues. And we have taken things and gone beyond... I think where we started in 1990 and today, there's a big improvement...(SM5).

Sri Lanka was always ahead of the game, because local regulations required us to pay attention to labour standards and conditions. In some instances - and certainly in some factories which were moving into high-end products - standards were over and above what was expected by numerous different initiatives... In this sense, ethical trading only "fine tuned" existing labour standards and conditions (SM3).

More generally, it is also clear that ethical trade debates need to take more serious account of the local context if they are to fully appreciate the differential implementation of corporate codes of conduct. Likewise, the multi-dimensional factors which underpin the complex impacts of ethical trade initiatives are vital to an appreciation of how sites of production are likely to respond in the face of downward economic pressure - particularly when that includes confronting a global recession 
While much has been said more generally in the academic literature about the processes that drive and govern the operation of global production networks and the relation between corporate and state actors, less has been discussed about the role of labour as an active constituent of the global economy (Cumbers et al., 2008, McIntyre 2008). Indeed, Sunley (2008) critically observes that the general debates on global production networks, within which the apparel industry has been analysed, have largely tended to focus on the ways in which 'specific modes of economic coordination or governance (...) based on strong ties and long-term, reciprocal relationships' appear to matter $(2008,4)$. The GPN literature has tended to hone in how such networks and relationships have beneficial impacts on strengthening the industry but has been relatively silent regarding what the up-scaling process means for labour practices and conditions. Yet, as Pickles et al. (2006) note, the variation in production processes matter for labour conditions as does the institutional context, and understanding the shifting dynamics of the global apparel sector requires these issues to be considered.

\section{Ethical trade initiatives—uneven playing fields?}

In the context of ethical codes of conduct, the voluntary nature of such codes has received academic critique (Blowfield, 1999; Pearson and Seyfang, 2001; Freidberg, 2003; Hughes, 2005). Corporate self-regulation has resulted in a high degree of variation in ethical trade strategies and subsequently, this has consequences for auditing practices and working conditions (Kabeer, 2004; Hughes, 2005; Barrientos and Smith, 2007; Hale and Wills, 2007). Furthermore, Freidberg's (2004) study of the ethical complex of food retailers has appropriately drawn attention to the contradictions in the 'ethical' sourcing strategies of buyers. She highlights that even though suppliers bear the cost of improved worker welfare, they are rarely rewarded by retailers with higher prices - or in the case of Sri Lanka, not even by guaranteed business or consistently larger orders:

Even though we have close connections with our main buyer and sometimes they have even offered us vital input when moving onto higher value added production, they really don't offer us guaranteed business. We like to think that we are a preferred supplier given the high standards at our factory, but the reality is we are one amongst many and they will not hesitate to make us recognize this. There is constant pressure for us to offer the best and most competitive garment... otherwise you might as well be dead. (SM13)

In this context, the existence of what were perceived to be double-standards displayed by retailers was commented by many of our interviewees:

Actually there are unfortunately double standards, although most of the retailers talk about the compliances, I don't think they are going to inner China checking up the factory. They are looking at a factory, most probably in Shanghai... and they think it is compliant; also in Bangladesh, which is currently doing extremely very well. But it is all about double-standards. I think the most important thing for the consumer and for the retailer today (with the recession) is the price. So, are we really paying for the compliances and all the things that we put in like air-conditioned plants, subsidized food, transport, etc? I don't know whether any of this makes us lose or gain competitiveness. (SM5). 
This apparent blind-eye that retailers turn to the low levels of compliance amongst regional competitors of Sri Lanka also consistently arose within our interviews. Similar concerns for other regions have also been highlighted by Impactt and Traidcraft (2009). The exploitation of weak regulatory structures by transnational retailers highlighted by Mayne (1999) is evident in the profound tensions perceived by our interviewees, between what merchandising teams prioritize when negotiating contracts with suppliers and what the corporate social responsibility codes of retailers require factories to adhere to.

Sometimes buyers are thinking of protecting their brands. They don't genuinely care about the workers... If they are concerned about compliance, Sri Lanka should be getting more business. Globally, price is given the first priority in the garment sector. (MM7)

... All of this would be ok if the buyers had a genuine commitment towards improving worker conditions. I don't think that this is the case at all, because if they were they should have an ethical buying policy and be willing to pay a premium for compliance - and accept a reduced profit margin on their part. This never happens; they never give up on their margins and ultimately and always it boils down to price. (SM9)

In debates on the effectiveness of corporate codes of conduct and other ethical trade initiatives on actors at the sites of production, there are numerous accounts (Barrientos and Smith, 2007; Hale and Wills, 2007) which have attempted to make judgements over whether these initiatives have made any real impact on previously non-compliant factories, or on the working conditions of garment labourers. For the most part, examples selected by academics have converged upon failing or non-compliant factories and the subsequent influence of initiatives on their circumstances. Far less attention has been devoted to complaint factories and their workers, with restrictive consequences for the nature of the debate (Blowfield, 2007). The neglect of the circumstances and initiatives occurring in countries, such as Sri Lanka, where labour laws appear strong and labour conditions prior to the arrival of corporate codes of conduct were generally better than in competing countries and where management practices have performed a significant role in maintaining such relatively high levels of working conditions is, we suggest, an important omission and an obstacle to more comprehensive understanding of ethical trade initiatives.

In this context, our Sri Lankan management interviews consistently flagged up how certain nationally and locally specific factors determine and mediate the implementation of corporate codes of conduct with management anxieties centring on the intense regional competition faced by Sri Lanka, despite the country's compliance with labour standards. Management also focused on the high degree of inconsistency surrounding the implementation of ethical trading initiatives across the region. These contradictions for many interviewees meant that ethical trade initiatives frequently constrained Sri Lankan suppliers in terms of attracting business. Achieving a compliant status, for example ETI approval, was seen as suppliers' cost of entry, with compliance never guaranteeing further orders or an increase in price.

They [buyers] are not going to tell you, 'if you are ETI-approved, I'm going to pay you two percent more'. That is your cost of entry - that's your price to do business. They don't differentiate by saying if you are unapproved, so that's your cost of entry. That's your price to 
do business. You have to be approved, but there's a cost. The playing field is not level when you take Bangladesh and China. But people turn a blind eye to that... (SM7).

Despite the apparent hallmark that comes from being 'ethical', the imposition of stringent standards and the associated inconsistencies frequently result in contradictions not sufficiently scrutinized in the literature. Managers in particular drew attention to the differentiated and relative nature of auditing:

\begin{abstract}
All these certifications... you know, everybody thinks WRAP certification is great, SAI8000 is great, ISO 9000 is great, ETI is great. It's just a perception... I see factories in Sri Lanka that have WRAP certification and have... very high standards - amazing. And they've been asked to redo stuff - little things - unbelievable... Then I go to a factory - let's say in Karachi where they've got child labour, harassment... and they still have a WRAP certification... It's the auditors. Let's say Bureau Veritas, ITS - that does the auditing in Sri Lanka, they audit by Sri Lankan standards. So they like 'My god to get WRAP you have to better than X or Y'. So, they are very strict on this. You go to Pakistan. They go and see a factory that might be substandard by Sri Lankan standards. But they think 'this is good enough for us'... It's very relative...(MM1).
\end{abstract}

These regional inconsistencies imply that less compliant countries, which may boast a competitive advantage in reserves of cheap labour, are likely to offer buyers more cost-effective options (see also Heintz, 2004; Knutsen, 2004). Thus, whilst it is vitally important to continue studying the successes and failings of ethical trade initiatives, the wider political, social and cultural contexts demand that research remains fully aware and alert to the local and regional discrepancies that tend to be exploited by the major global retailers, brand manufacturers and the dynamics of the garment industry. The reality of corporate codes of conduct implementation remains desperately disjointed from the moral ideals and standards which corporate social responsibility strategies, global and national labour authorities and civil society organizations have strived to achieve through the deployment of these ethically driven programmes.

\title{
5. Squeezed to the bone! The costs of maintaining compliance during global economic crisis
}

The disjuncture between the priorities of merchandizing and corporate social responsibility units of retailers, unsurprisingly then feeds into the anxieties of apparel manufacturers conveyed to us during interviews. Our Sri Lankan management interviews conducted as the global recession reached its low point, not only offered insights into the struggles suppliers confront in the face of pressure from retail buyers, NGOs and auditing bodies, but usefully shed light upon the extra pressures associated with maintaining compliance during economic crisis.

A common theme of our interviews was that the sourcing priorities of major retailers had become even more focused upon price and maintenance of profit margins, and were displaying even less lenience towards compliant suppliers than in the pre-global downturn period.

Even though buyers speak of codes and compliance, our experience at the moment tells us that pricing is the bottom-line. When a buyer places an order with us, we price the garment for 
production from our factories in Sri Lanka as well as Bangladesh, say for example - in short, from within the group. We make the buyer aware that the Sri Lankan product is priced higher because they have to pay a premium for compliance and higher costs associated with the codes and implementing them rigorously. Often the buyer tends to choose the product from one of our factories in the region ... where, well, the labour standards are lower... This has happened more frequently in the past few months... and yes, so this is how we find the recession affecting the production-end of codes (MM7)

During interviews, managers consistently returned to the way global economic crisis was posing a threat to their business. In turn, that was inevitably resulting in suppliers cutting back on their labour costs:

[The global economic recession] is one of the biggest challenges for us now. One thing is- it's going to hit the sales... Once the sales drop, we will feel it.... we have to try and squeeze from somewhere - our margins, factories, etc. The choice is either closing down the factory or getting people to work at lower rates, less hours, etc... (SM4).

... The overseas crisis, like (in the) US and Europe, they're squeezing us to the bone... They don't justify [lowering costs]. They actually don't take any dropdown. They don't give you premium for your compliance... (MM5).

And in this context the ethical stance of Sri Lankan manufacturers was perceived to be exacerbating the tensions. The consensual view was that there appeared to be little room in a global recession for retailers to maintain ethical standards, other than to protect a public image amongst their customers in the Global North. Indeed, several managers went so far as to claim that Sri Lanka was essentially offered small orders only in order that retailers could protect themselves from negative publicity by claiming that they source from ethically sound countries, such as Sri Lanka.

Look, I have been on both sides of the industry - working first for suppliers and now for a buyer. Now that I'm on this side (buyer), I see this all the time... we mostly buy from Sri Lanka because we know that most often the factories are excellent. This way, we protect ourselves. But we really don't place bulk orders there, because good factories mean higher overheads and paying higher prices. Price - rather than ethical standards - is the underlying issue and so we also place orders in Bangladesh, China, Vietnam and place larger volumes in those places. I'm telling you this, because it makes me $\mathrm{p}^{* * *}$ off when there is talk of ethical codes and little effort at following this through when it comes to merchandising. The recession has made this much more acute (MM12)

... otherwise, they (the buyers) can go and put all their business in China. China will and can absorb everything that Sri Lanka exports, in terms of volume. So why are they continuing to romance and dance us? I think the answer is because we are ethical - but they are not willing to pay us higher prices for this or giving us larger volume. It is a concern that is being brought up strongly, especially now ... in the context of a recession (MM4)

The dilemma faced by suppliers who must attempt simultaneously to retain orders and prevent capital flight while promoting compliance and labour standards has been scrutinized in general terms in previous academic studies (Hale and Shaw, 2001; Heintz, 2004), albeit that Nadvi (2008) asserts that detailed evidence on the outcomes of standards for actors at the site of production is limited. The findings emerging from our 
Sri Lankan management interviews suggest that these tensions have significantly increased during the global economic recession.

They (the merchandisers) should be looking at it... according to the ranking system, we give them plus points for these good standards factories. And, the merchants have the access to this ranking system. When they are placing orders, they know about the ranking system... Its' troubling to say this, but what I find more and more during this recession is that the merchandisers are placing orders with factories in other countries that are ranked lower. (MM3)

But buyers say compliance rather than price is the issue, (and the former) is used as the rationale for divesting... This has happened; for example, X says it isn't satisfied by the price, but they also say 'compliance, quality and delivery' - and they use the latter rather than pricing as the issue: an easy way out... And we have seen more and more of this happening at the moment. My sense is that this way, buyers evade responsibility, especially now that there is crisis going-on. (MM2)

Feeling compromised and restricted in their possible practical and strategic responses, given the prioritization of price over compliance by buyers, suppliers find themselves in a risky and helpless position when attempting to meet deadlines and arranging overtime agreements with workers. This has become increasingly the case during the economic crisis. The shorter lead times and smaller order quantities which have accompanied the recession have put pressure on the stretching of overtime hours, with smaller factories struggling to survive:

... gradually with the recession most of the sub-contractors are dying ... because there are not enough orders for them and another thing is prices are coming down so badly. And what the larger factories may sub-contract, if this is possible, are small quantities, which makes it difficult for them. (SM9)

...look, we all know that the industry sub-contracts. This is not a secret. But the factories we sub-contract to aren't necessarily small-sized factories; sometimes we have placed sub-contract orders with a factory which belongs to X...A Also, not all these smaller factories necessarily have lower standards than us; in fact, $\mathrm{Y}$ requires us to ensure that any sub-contracted orders adhere to all the codes that we ourselves have to maintain. The onus is on us then. The danger of the current economic crisis is that it will tip some of the small factories which have good standards as being ethical means having higher overhead costs. This, simply because they can not cover their margins with the smaller orders or lower prices or the short lead times - and recently with the crisis a combination of all factors.' (SM10)

In a context where producers, large and small, have scrambled to get whatever orders they can of a reasonable magnitude and price, and in a context of increasingly tight lead times, our interviewees freely admit to a rise in double book-keeping and to a lesser extent bribery.

Lately, when we are given real short lead times, meeting production targets while remaining within the codes means that we can not deliver the order on time. If we miss the shipment, then we have to pay airfreight, which is more costly and can not be done when the margins are tight. Invariably, it means overtime which goes against our own (local) laws... and because of this we maintain separate sheets. Sometimes we inform our buyers that we are doing this too as we don't have many options if we are to survive. (SM8) 
The general challenge posed to suppliers in terms of meeting shorter deadlines of small and constantly changing garment styles, whilst not exceeding overtime limits for example is an issue previously discussed in the literature by Nadvi (2008) and Heintz (2004). Interestingly, Heinz (2004) concludes that raising labour standards may not actually help ameliorate the well-being of workers in the Global South, because of the sorts of unintended consequences cited by our Sri Lankan interviewees - consequences which appear to have been intensified by the global downturn (see also Impactt and Traidcraft, 2009). Nadvi (2008) similarly questions the benefits that are seen by compliant suppliers, and like Heinz concludes that compliance with global standards is likely to prove ineffective in improving working conditions and labour standards of factory employees. As Barrientos and Smith (2007) suggest, buyers' sourcing strategies are in fundamental ways inherently incompatible with and undermine the implementation of corporate codes of conduct at sites of production. And this inherent incompatibility has been deepened by the global economic crisis.

\section{Conclusion}

The literature on the rise of global labour standards has been extensive and economic geographers have made a distinctive contribution to its development (Smith et al., 2002; Pickles et al., 2006). The majority of studies have focused on the international drivers behind such standards and how they are being implemented in GVCs (McIntyre, 2008; Nadvi, 2008). While this literature has considerably significantly enriched the ethical trade debates, and has been complemented by investigation of the limitations of corporate codes it has been less extensive in the coverage of the impact of standards and codes at sites of production. Equally, there has been a relative neglect in this literature regarding the ways in which national regulation and labour histories of countries in the Global South may have played a pivotal role in ensuring retailer-led code regulation are more likely to be upheld. Sri Lanka, offers one such illustration.

While important contributions have been made that highlight the inconsistencies, outcomes and apparent failings of those corporate codes of conduct, the implications for suppliers and the contradictions suppliers perceive in those initiatives remain under-researched. Our article has provided evidence of the management-level anxieties and frustrations frequently mentioned but underexplored in debates about ethical trade initiatives and their impacts at sites of production. Our evidence has highlighted the nuanced realities for managers and gone some way to reveal the lived experiences of corporate codes of conduct in the workplace. Even though Sri Lanka has had an impressive labour movement history and a regulatory framework, which has assisted labourers evade the exploitative work conditions of its neighbouring countries (Candland, 2002), honing in on the institutional context during a moment of economic crisis helps appreciate the ways in which uneven development patterns remain at the core of global capitalism (McIntyre, 2008; Sunley, 2008). In this regard, appreciating the economic power and social relations that structure the implementation of ethical trading codes shows the limits to their efficacy-despite in this case a national regulatory context with some protective labour laws and historically high social and human development. In this regard our analysis moves beyond existing academic contributions on value chain and network-based relational economic geographies, 
where there is a propensity to neglect local configurations as they confront the global economy (Smith et al., 2002; Bair 2005, 154). Instead we assert the central importance of considering institutional factors, social development, labour histories and national regulatory regimes as they intersect with ethical trading codes of conduct - not least because structural facets such as these may bring about particular developmental outcomes (Bair, 2005; Sunley, 2008; Tokatli et al., 2008).

We argue then that assessments of the impact of corporate codes of conduct require appreciation of the economic, social, political and institutional context in which production takes place in order to understand the implementation of codes of labour practice (Pickles et al., 2006; Barrientos and Smith, 2007; McIntyre, 2008). In this regard, our article provides an example of how country-specific contingencies mediate the impact of ethical labour initiatives to a significant degree. In particular, our article has attempted to link the national and local context to the forces of the global economy, whereby ethical concerns are seen to have become vulnerable to pressures of economic downturn. Such an analysis also underscores the need to explore tensions that exist between global governance regimes and national regulations, and how they are likely to become more acute during times of economic crisis. In turn, this suggests the need for more extensive investigations of the practical and strategic management-level responses adopted to cope with the costs of compliance, in order to appreciate how codes of conduct and social auditing practices have impacted upon.

Additionally, we argue that this is a useful starting point in understanding how codes impacted upon work practices and work organization during economic recession. Bair $(2005,171)$ reminds us with regard to the GVC literature that by expanding the scope to analyse local and global regulatory mechanisms and their intersections with global capitalism it is possible to acknowledge the inequities embedded in the global economy and how firms, workers and communities, have different leveraging positions in the global/local economic continuum. Without acknowledging these dynamics during times of economic crisis it becomes impossible to uncover the ways in which uneven development processes are perpetuated with uneven distributional outcomes to its constituents. While much research work remains yet to be completed, our article provides early documentation of the impact of global recession in ethical trade and compliance at sites of production. We anticipate that the question of whether ethical trading policies are likely to have been significantly and adversely impactedand in what form they have emerged from the global recession crisis of 2007-2009 is an issue that will attract considerable academic attention in the short to medium term. Our Sri Lankan manufacturers interviews conducted during the depth of the recession offer early insight into the challenges to corporate codes of conduct and social auditing practices at sites of production during this period. Additionally, they highlight both the uneven distribution and uncertain returns from the costs of compliance.

\section{Funding}

The authors wish to acknowledge the support of an Economic and Social Science Research (ESRC) Council grant (RES-061-25-0181), which funded the initial phase of the fieldwork from which this paper is written. 


\section{Acknowledgements}

The first author wishes to acknowledge Alex Magee's superb research assistance in doing background research for this article and the School of Geography's Summer Student Bursary Scheme (2009), which made his placement possible. The authors wish to thank Martin Buttle for taking his time to read and offer comments on a previous version of this article, and to Andrew Jones (Birkbeck College, London) for going beyond his usual tasks and taking on the managing editor role for this article and facilitating the review process for us.

\section{References}

Bair, J. (2005) Global capitalism and commodity chains: looking back, going forward. Competition and Change, 9: 153-180.

Bair, J. (2006) Regional trade and production blocks in a global industry. Environment and Planning A, 38: 2233-2252.

Barrientos, S., Smith, S. (2007) Do workers benefit from ethical trade? Assessing codes of labour practice in global production systems. Third World Quarterly, 28: 713-729.

Blowfield, M. (1999) Ethical trade: A review of developments and issues. Third World Quarterly, 20: $753-770$.

Blowfield, M. (2007) Reasons to be Cheerful? What we know about CSR's Impact. Third World Quarterly, 28: 683-695.

Candland, C. (2002) The political element in economic reform: labour institutions and privatization patterns in South Asia. In M. P. Posusney, L. J. Cook (eds) Privatization and Labour: Responses and Consequences in Global Perspective, pp. 65-82. Chelthenham: Edward Elgar.

Coe, N.M., Dicken, P., Hess, M. (2008) Global production networks: realizing the potential. Journal of Economic Geography, 8: 271-295.

Cumbers, A., Nativel, C., Routledge, P. (2008) Labour agency and union positionalities in global production networks. Journal of Economic Geography, 8: 369-387.

De Neve, G. (2009) Power, inequality and corporate social responsibility: the politics of ethical compliance in the South Indian garment industry. Economic and Political Weekly, XIV: $63-71$.

Friedberg, S. (2003) Cleaning up down South: supermarkets, ethical trade and African horticulture. Social and Cultural Geography, 4: 27-43.

Friedberg, S. (2004) The ethical complex of corporate food power. Environment and Planning D: Society and Space, 22: 513-531.

Gereffi, G., Humphrey, J., Sturgeon, T. (2005) The governance of global value chains. Review of International Political Economy, 12: 78-104.

Gunawardana, S. (2007) Struggle, Perseverance and organization in Sri Lanka's export processing zones. In K. Bronbenbrenner (ed.) Global Unions: Challenging Transnational Capital Through Cross-Border Campaigns, pp. 78-98. Ithaca: Cornell University Press.

Gunawardana, S., Biyanwila, J. (2008) Trade unions in Sri Lanka: beyond party politics. In J. Benson, Y. Zhu (eds) Trade Unions in Asia: Balancing Economic Competitiveness and Social Responsibility, pp. 177-197. London: Routledge.

Hale, A. (2000) What hope for ethical trade in the globalised garment industry? Antipode, 32: 349-356.

Hale, A., Shaw, L.M. (2001) Women workers and the promise of ethical trade in the globalised garment industry: a serious beginning? Antipode, 33: 510-530.

Hale, A., Wills, J. (2007) Women working worldwide: transnational networks, corporate social responsibility and action research. Global Networks, 7: 453-476.

Heintz, J. (2004) Beyond sweatshops: employment, labour market security and global inequality. Antipode, 36: 222-226.

Hewamanne, S. (2008) Stitching Identities in a Free Trade Zone: Gender and Politics in Sri Lanka. Philadelphia: University of Pennsylvania Press.

Hughes, A. (2005) Corporate strategy and the management of ethical trade: the case of the UK food and clothing retailers. Environment and Planning A, 37: 1145-1163. 
Hughes, A. (2001) Multi-stakeholder approaches to ethical trade: towards a reorganization of UK retailers' global supply chains? Journal of Economic Geography, 1: 421-437.

Hughes, A., Buttle, M., Wrigley, N. (2007) Organisational geographies of corporate responsibility: a UK-US comparison of retailers' ethical trading initiatives. Journal of Economic Geography, 7: 491-513.

Hughes, A., Wrigley, N., Buttle, M. (2008) Global production networks, ethical campaigning and the embeddedness of responsible governance. Journal of Economic Geography, 8: 345-367.

Impactt/Traidcraft, (2009) Material Concerns: How Responsible Sourcing Can Deliver Goods for Business and Workers in the Garment Industry. Working Report.

Jayawardena, K. (1972) The Rise of the Labour Movement in Ceylon. North Carolina: Duke University Press.

Kabeer, N. (2004) Globalization, labour Standards, and women's rights: dilemmas of collective (in)action in an interdependent world. Feminist Economics, 10: 3-35.

Karp, J. (1999) Sri Lanka keeps Victoria's secret: island workers produce panties in cool comfort. Wall Street Journal, 13 July: B1, B4.

Knutsen, H.M. (2004) Industrial development in buyer-driven networks: the garment industry in Vietnam and Sri Lanka. Journal of Economic Geography, 4: 545-564.

Lynch, C. (2007) Juki Girls, Good Girls: Gender and Cultural Politics in Sri Lanka's Global Garment Industry. Ithaca: Cornell University Press.

Mayne, R. (1999) Regulating TNCs: the role of voluntary governmental approaches. In S. Picciottol, R. Mayne (eds) Regulating International Business, pp. 235-253. London: McMillan.

McIntyre, R. (2008) Are Worker Rights, Human Rights?. Ann Arbor: University of Michigan Press.

Nadvi, K. (2008) Global standards, global governance and the organization of global value chains. Journal of Economic Geography, 8: 323-334.

Neidik, B., Gereffi, G. (2006) Explaining Turkey's emergence and sustained competitiveness as a full-package supplier of apparel. Environment and Planning A, 38: 2285-2303.

O'Leary, M. (2009) Responsible garment management. Serendib, November/December 2008: 68-70.

Palpaceur, F., Gibbon, P., Thomsen, L. (2005) New challenges for developing country suppliers in global clothing chains: a comparative European perspective. World Development, 33: 409-430.

Pearson, R., Seyfang, G. (2001) New hope or false dawn?: Voluntary codes of conduct, labour regulation and social policy in a globalizing world. Global Social Policy, 1: 49-78.

Pickles, J., Smith, A., Bucěk, M., Roukova, P., Begg, R. (2006) Upgrading, changing competitive pressures, and diverse practices in the East and Central European apparel industry. Environment and Planning A, 38: 2305-2342.

Ranaraja, S. (2004) A comparative study on international labour standards, national law and codes of conduct in the Apparel Sector. Research Paper. ILO, Colombo.

Saravanathan, M., Sanjeewani, H.M.P. (2008) Has GSP+ Contributed to Poverty Reduction and Fostered Sustainable Development in Sri Lanka? GSP+ and Sri Lanka: Economic, Labour and Human Rights Issues. Colombo: Centre for Policy Alternatives and Friedrich Ebert Stiftung.

Schoenberger, E. (1991) The corporate interview as a research method in economic geography. The Professional Geographer, 43: 180-189.

Sluiter, L. (2009) Clean Clothes: A Global Movement to End Sweatshops. New York: Pluto Press.

Smith, A., Rainnie, A., Dunford, M., Hardy, J., Hudson, R., Sadler, D. (2002) Networks of value, commodities and regions: reworking divisions of labour in macro-regional economies. Progress in Human Geography, 26: 41-63.

Sunley, P. (2008) Relational economic geography: a partial understanding or a new paradigm? Economic Geography, 84: 1-26.

Tewari, M. (2006) Adjustment in India's textile and apparel industry: reworking historical legacies in a post-MFA world. Environment and Planning A, 38: 2325-2344.

Tokatli, N. (2007a) Assymetrical power relations and upgrading among suppliers of global clothing brands: Hugo Boss in Turkey. Journal of Economic Geography, 7: 67-92. 
Tokatli, N. (2007b) Networks, firms and upgrading within the blue-jeans industry: evidence from Turkey. Global Networks, 7: 51-68.

Tokatli, N. (2008) Global sourcing: insights from the global clothing industry - the case of Zara, as fast fashion retailer. Journal of Economic Geography, 8: 21-38.

Tokatli, N., Wrigley, N., Kizilgun, O. (2008) Shifting global supply networks and fast fashion: made in Turkey for Marks and Spencer. Global Networks, 8: 261-280.

Webber, M., Weller, S. (2001) Trade and inequality: Australia's textile, clothing and footwear industries, 1986-1996. Journal of Economic Geography, 1: 381-403.

Weller, S. (2007) Fashion as viscous knowledge: fashion's role in shaping trans-national garment production. Journal of Economic Geography, 7: 39-66.

Wijesuriya (2008) Shall we close our garment factories? The Island: Features, 9th November 2007, p. A1.

Yatawara, R.A. (2007) Gender-related Labour Transition Issues Resulting from the Expiration of the Agreement on Textiles and Clothing (ATC). Working Paper. Colombo: Institute of Policy Studies.

\section{Appendix A}

Table A1. Characteristics of interviewees

\begin{tabular}{llr}
\hline Typology & Key characteristics & Numbers \\
\hline \multirow{2}{*}{ Management rank } & Senior management (CEOs, Country Directors, Managing and & 13 \\
& Group Directors) & 12 \\
& Middle management (General Managers, Factory Managers, CSR & \\
Organization type & Buying offices based in Sri Lanka (of USA and UK retail brands) & 4 \\
& Foreign-owned factories in Sri Lanka & 3 \\
Size & Locally owned factories in Sri Lanka & 18 \\
& Large-size suppliers & 5 \\
& Middle-size suppliers & 15 \\
Factory locations & Small size suppliers & 5 \\
& All-island & 18 \\
& Rural-only & 5 \\
& Free-trade zone only & 2 \\
\hline
\end{tabular}

